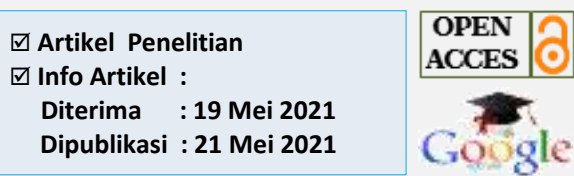

\title{
Faktor Komorbid terhadap Covid-19 di Puskesmas Kota Tahun 2020
}

\author{
Merlin LD Ndera ${ }^{1}$, Nani Supriyatni ${ }^{2 \bowtie}$ dan Agustin Rahayu ${ }^{2}$ \\ 1 Pegawai di Puskesmas Kota Ternate dan Mahasiswa Fakultas Ilmu Kesehatan, Universitas Muhammadiyah Maluku Utara. \\ Ternate-Indonesia, Email : 1linkarlina671@gmail.com \\ 2 Staf Pengajar Fakultas Ilmu Kesehatan, Universitas Muhammadiyah Maluku Utara. Ternate-Indonesia, \\ Email : naniskm@yahoo.com; agustinyayu21@gmail.com
}

${ }^{\square}$ Korespondensi : Nani Supriyatni, Universitas Muhammadiyah Maluku Utara. Ternate-Indonesia,

Email : naniskm@yahoo.com

\begin{abstract}
ABSTRAK
Penyakit kronis menyebabkan sistem kekebalan tubuh penderitanya melemah dan lebih sulit melawan infeksi. Akibatnya, tubuh penderita penyakit kronis akan lebih mudah terserang penyakit, termasuk Covid-19 yang disebabkan oleh infeksi virus Corona (Yurianto,2020). Covid-19 ini bisa menyerang hampir seluruh kalangan usia, namun demikian data yang ada saat ini menunjukkan bahwa kelompok usia lanjut dan orang yang mempunyai riwayat penyakit kronis (ko-morbid) memiliki risiko untuk terkena lebih sering dan dengan komplikasi yang lebih buruk dari penyakit ini. Riwayat penyakit kronis yang dimaksud antara lain adalah hipertensi, diabetes melitus, penyakit kardiovaskuler, dan penyakit paru kronis. Khusus untuk mereka dengan diabetes, merupakan komorbiditas kedua tersering ditemukan, sekitar 8\% kasus, setelah hipertensi, dan dengan angka kematian tiga kali lipat dibandingkan penderita secara umum (7.3\% berbanding 2.3\%), (PB PERKENI,2020) Tujuan : Untuk mengetahui Pengaruh Komorbid terhadap Covid-19 di wilayah Kerja Puskesmas Kota Ternate Tahun 2020 Metode: Jenis penelitian ini adalah penelitian observasi analitik, dengan desain cross sectional study. Lokasi penelitian di Wilayah Kerja Puskesmas Kota Ternate dengan populasi adalah semua pasien penderita covid-19 yang berjumlah 108 responden Di wilayah kerja puskesmas Kota Ternate Tahun 2020 Hasil : hasil analisis menunjukkan bahwa Ada pengaruh dimana pasien komorbid lebih bersiko akan terkena covid 19. Yaitu pasien covid-19 dengan hipertensi $(p=0,002)$, diabetes mellitus $(p=0,000)$, dan asma $(p=0,001)$. Sedangkan tidak ada pengaruh pasien Covid 19 dengan disertaai pneumonia $(p=0,671)$. Hasil analisis multivariate bahwa pengaruh diabetes mellitus terhadap covid-19 dengan nilai signifikan p 0.037 merupakan faktor komorbid yang sangat berpengaruh 3.385 kali lipat pada penderita Covid-19. Penderita Covid-19 dapat meningkatkan kesadaran dan kewaspadaan terhadap kondisi kesehatannya dengan selalu menjaga sisitim imun tubuh dan melakukan protocol kesehatan.
\end{abstract}

Keyword: covid-19, hypetensi, DM, Asma, Pneumonia

\section{PENDAHULUAN}

Pada Desember 2019, kasus pneumonia misterius pertama kali dilaporkan di Wuhan, Provinsi Hubei. Sumber penularan kasus ini masih belum diketahui pasti, tetapi kasus pertama dikaitkan dengan pasar ikan di Wuhan. Tanggal 18 Desember hingga 29 Desember 2019, terdapat lima pasien yang dirawat dengan Acute Respiratory Distress Syndrome (ARDS). Sejak 31 Desember 2019 hingga 3 Januari 2020 kasus ini meningkat pesat, ditandai dengan dilaporkannya sebanyak 44 kasus. Tidak sampai satu bulan, penyakit ini telah menyebar di berbagai provinsi lain di China, Thailand, Jepang, dan Korea Selatan.Sampel yang diteliti menunjukkan etiologi coronavirus baru. (Huang, 2019).

Awal tahun 2020, COVID-19 menjadi masalah kesehatan dunia, sehingga pada tanggal 30 Januari 2020, WHO menetapkan COVID-19 sebagai Public Health Emergency of International Concern (PHEIC)/ Kedaruratan Kesehatan Masyarakat Yang Meresahkan Dunia (KKMMD). Pada tanggal 12 Februari 2020, WHO resmi menetapkan penyakit coronavirus pada manusia ini dengan sebutan 
Coronavirus Disease (COVID19), pada tanggal 2 Maret 2020 Indonesia telah melaporkan terdapat 2 kasus konfirmasi COVID-19, Dan tanggal 11 Maret 2020, WHO sudah menetapkan COVID-19 sebagai pandemik. (Dirjen P2PL kemkes, 2020).

Tanggal 30 Januari 2020, telah terdapat 7.736 kasus terkonfirmasi COVID-19 di China, dan 86 kasus lain dilaporkan dari berbagai negara seperti Taiwan, Thailand, Vietnam, Malaysia, Nepal, Sri Lanka, Kamboja, Jepang, Singapura, Arab Saudi, Korea Selatan, Filipina, India, Australia, Kanada, Finlandia, Prancis, dan Jerman. COVID-19 pertama dilaporkan di Indonesia pada tanggal 2 Maret 2020 sejumlah dua kasus. Data 31 Maret 2020 menunjukkan kasus yang terkonfirmasi berjumlah 1.528 kasus dan 136 kasus kematian.Amerika Serikat menduduki peringkat pertama dengan kasus COVID19 terbanyak dengan penambahan kasus baru sebanyak 19.332 kasus pada tanggal 30 Maret 2020 disusul oleh Spanyol (Kemkes, 2020).

Virus corona rentan menginfeksi orang-orang yang sebelumnya memiliki penyakit bawaan. Menurut beberapa studi, orang yang terinfeksi virus Corona dan menderita penyakit kronis memiliki risiko lebih tinggi untuk mengalami gejala berat yang fatal, seperti halnya pada lansia (PERKENI,2020).

Penyakit komorbid pada Covid-19 itu dapat berupa hipertensi atau tekanan darah tinggi, diabetes, jantung, paru-paru obstruktif kronis (PPOK), asma, tuberkulosis (TBC), dan demam berdarah dengue. NamunPenyakit penyerta pada mereka yang positif virus paling banyak adalah hipertensi, diabetes melitus, heart disease (penyakit kardiovasekuler), dan penyakit paru obstruksi kronis (Yurianto Ahmad,2020).

Hingga tanggal 29 Juli 2020, terdapat 634.835 kasus dan 33.106 jumlah kematian di seluruh dunia. Sementara di Indonesia per Juli 2020 sudah ditetapkan 104.432 kasus dengan positif Covid-19 dan 4.975 kasus meninggal dunia. Berdasarkan data perkembangan Covid-19 provinsi maluku utara selasa 28 Agustus 2020 adalah 1.779 jiwa pasien terkonfirmasi Covid-19, dengan angka kematian 61 jiwa. Sedangkan data Dinas Kesehatan Kota Ternate terdapat 721 kasus konfirmasi Covid-19 dengan angka kematian 19 jiwa. (Dinas Kesehatan Provinsi Maluku Utara, 2020).

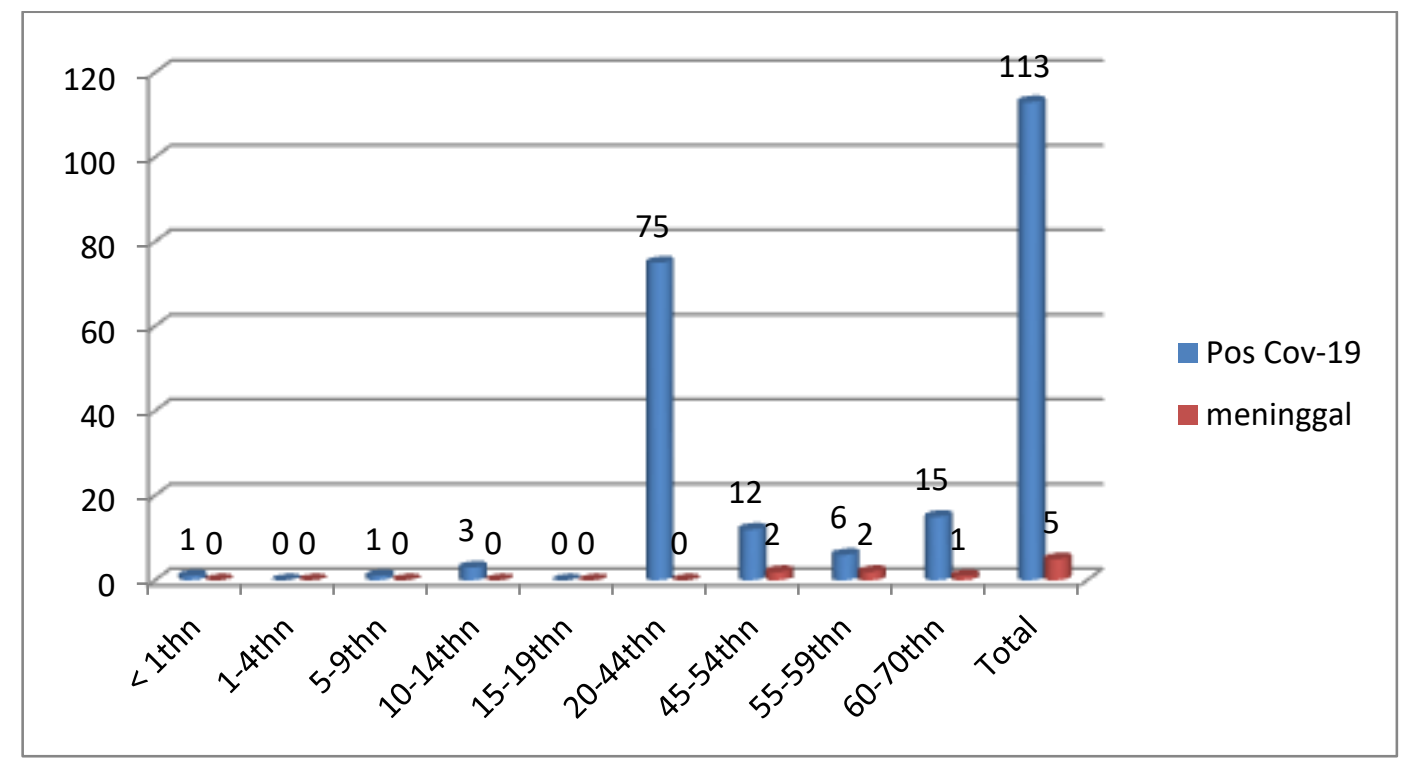

Gambar 1. Data Penderita Covid-19 Wilayah Kerja Puskesmas Kota Tahun 2020. Sumber : Data Puskesmas Kota, Agustus:2020

Gambar 1. menunjukkan bahwa penderita Covid-19 di wilayah kerja Puskesmas Kota sebanyak 113 orang terkonfirmasi covid-19 (positif), dan 5 orang meninggal ( Puskesmas Kota,2020).

\section{METODE PENELITIAN}

Jenis penelitian ini adalah penelitian observasi analitik, dengan desain cross sectional study. Penelitian dilakukan pada tanggal 19 sampai dengan 22 Oktober Tahun 2020 di Wilayah Kerja 
Puskesmas Kota Ternate. Populasi dan sampel adalah semua pasien penderita covid-19 yang berjumlah 108 responden. Analisis data menggunakan Multivariat uji regresi logistik.

\section{HASIL DAN PEMBAHASAAN}

3.1. Analisis Univariat

a. Distribusi Responden Berdasarkan Golongan Umur

Tabel 1. Distribusi Responden Menurut Umur di Puskesmas Kota Tahun 2020

\begin{tabular}{ccc}
\hline Umur & $\mathbf{N}$ & $\mathbf{\%}$ \\
\hline 0-1 tahun & 1 & 0.9 \\
2-10 tahun & 2 & 1.9 \\
11-19 tahun & 3 & 2.8 \\
20-60 tahun & 87 & 80.6 \\
$>$ 60 tahun & 15 & 13.9 \\
\hline Total & $\mathbf{1 0 8}$ & $\mathbf{1 0 0 . 0}$ \\
\hline Sumber data primer, 2020 & &
\end{tabular}

Tabel 1 menunjukan bahwa distribusi responden berdasarkan golongan umur yang paling tertinggi adalah 20-60 tahun dengan jumlah sebanyak $87(80,6 \%)$ resonden, dan terendah dengan golongan umur 0-1 tahun berjumlah 1 responden (0.9\%).

b. Distibusi responden berdasarkan jenis kelamin

Tabel 2. Distribusi Responden Menurut Jenis Kelamin di Puskesmas Kota

\begin{tabular}{|c|c|c|}
\hline Jenis kelamin & $\mathbf{N}$ & $\%$ \\
\hline Laki-laki & 56 & 51.9 \\
\hline Perempuan & 52 & 48.1 \\
\hline Total & 108 & 100.0 \\
\hline
\end{tabular}

Sumber data primer. 2020

Berdasarkan tabel 2 menunjukan bahwa dari 108 responden terbanyak yang berjenis kelamin laki-laki yaitu $56(51,9 \%)$ responden, dibandingkan dengan yang berjenis kelamin perempuan hanya $52(48,1 \%)$ responden.

c. Distribusi responden berdasarkan pendidikan

Tabel 3. Distribusi Responden Menurut Pendidikan di Puskesmas Kota Tahun 2020

\begin{tabular}{|c|c|c|}
\hline Pendidikan & $\mathbf{N}$ & $\%$ \\
\hline Belum sekolah & 2 & 1.9 \\
\hline Belum tamat SD & 1 & .9 \\
\hline Tamat SD & 3 & 2.8 \\
\hline Tamat SMA & 43 & 39.8 \\
\hline D3 (DIPLOMA) & 13 & 12.0 \\
\hline S-1 & 44 & 40.7 \\
\hline S-2 & 2 & 1.9 \\
\hline Total & 108 & 100.0 \\
\hline
\end{tabular}

Sumber data primer, 2020

Tabel 3 menunjukan bahwa distribusi responden menurut tingkat pendidikan yaitu dari 108 respoden terbanyak yang lulusan S-1 adalah sebanyak $44(40,7 \%)$ responden, dan terendah yang belum tamat SD sebanyak $1(0,9 \%)$ responden. 


\section{d. Distribusi responden berdasarkan pekerjaan}

Pada Tabel 4 menunjukan bahwa distribusi responden berdasarkan pekerjaan yaitu dari 108 responden yang terbanyak adalah PNS dan Karyawan Swasta berjumlah masing-masin 34 (31,5\%) responden, dan terendah adalah belum bekerja $1(0,9 \%)$ responden.

Tabel 4. Distribusi Responden Menurut Pekerjaan di Puskesmas Kota Tahun 2020

\begin{tabular}{lcc}
\hline \multicolumn{1}{c}{ Pekerjaan } & N & \% \\
\hline Ibu rumah tangga (irt) & 8 & 7.4 \\
Tidak bekerja & 4 & 3.7 \\
Pns & 34 & 31.5 \\
Karyawan swasta & 34 & 31.5 \\
Polisi & 8 & 7.4 \\
Tni & 5 & 4.6 \\
Pelajar & 7 & 6.5 \\
Pensiunan & 5 & 4.6 \\
anggota DPR & 2 & 1.9 \\
Belum bekerja & 1 & 0.9 \\
\hline Total & $\mathbf{1 0 8}$ & $\mathbf{1 0 0 . 0}$ \\
\hline Sumber data primer, 2020 & &
\end{tabular}

\section{e. Distribusi responden berdasarkan riwayat perjalanan}

Pada Tabel 5 menunjukan bahwa responden yang bepergiantaua mempunyai riwayat perjalanan sebelumnya adalah sebanyak $9(8,3 \%)$ responden, dan responden yang tidak bepergian sebanyak $99(91,7 \%)$ responden.

Tabel 5. Distribusi Responden Menurut Riwayat Perjalanan di Puskesmas Kota Tahun 2020

\begin{tabular}{ccc}
\hline \multicolumn{1}{c}{ Riwayat Perjalanan } & $\mathbf{N}$ & $\mathbf{\%}$ \\
\hline Ya (bepergian) & 9 & 8.3 \\
Tidak (bepergian) & 99 & 91.7 \\
\hline Total & $\mathbf{1 0 8}$ & $\mathbf{1 0 0 . 0}$ \\
\hline
\end{tabular}

Sumber data primer, 2020

\section{f. Distribusi responden berdasarkan penderita covid-19}

Pada Tabel 6 menunjukan bahwa responden penderita covid-19 yang parah sebanyak 25 $(23,1 \%)$ sedangkan responden yang tidak parah sebanyak $83(76,9 \%)$ responden.

Tabel6. Distribusi Responden Menurut tingkat keparahan Covid-19 di Puskesmas Kota Tahun 2020

\begin{tabular}{lccc}
\hline & Covid-19 & N & \% \\
\hline Parah & & 25 & 23.1 \\
Tidak parah & & 83 & 76.9 \\
\hline & Total & $\mathbf{1 0 8}$ & $\mathbf{1 0 0 . 0}$ \\
\hline
\end{tabular}

Sumber data primer, 2020

g. Distribusi responden berdasarkan kontak pasien positif

Pada Tabel 7 menunjukan bahwa dari 108 responden, terdapat $49(45,4 \%)$ responden yang kontak dengan pasien positif, dan $59(54,6 \%)$ responden yang tidak kontak dengan pasien positif.

Tabel 7. Distribusi Responden Berdasarkan Kontak Pasien Positif di Puskesmas Kota Ternate Tahun 2020

\begin{tabular}{cccc}
\hline \multicolumn{2}{c}{ Kontak Pasien positif } & $\mathbf{N}$ & $\mathbf{\%}$ \\
\hline ya (kontak) & 49 & 45.4 \\
tidak (kontak) & 59 & 54.6 \\
\hline \multicolumn{2}{c}{ Total } & $\mathbf{1 0 8}$ & $\mathbf{1 0 0 . 0}$ \\
\hline
\end{tabular}

Sumber data primer, 2020 


\section{h. Distribusi responden Pasien Covid dengan Hipertensi}

Pada tabel 8 menunjukan bahwa dari 108 responden berdasarkan tekanan darah terdapat yang menderita hipertensi sebanyak $20(18,5 \%)$, dan yang tidak menderita hipertensi sebanyak 88 $(81,5)$ responden.

Tabel 8. Distribusi Responden Pasien Covid 19 Disertai Hipertensi di Puskesma Kota Tahun 2020

\begin{tabular}{|c|c|c|}
\hline Tekanan Darah & $\mathbf{N}$ & $\%$ \\
\hline Hipertensi & 20 & 18.5 \\
\hline Tidak hipertensi & 88 & 81.5 \\
\hline Total & 108 & 100.0 \\
\hline
\end{tabular}

Sumber data primer, 2020

\section{i. Distribusi responden berdasarkan Diabetes Mellitus}

Pada Tabel 9 menunjukan bahwa distribusi responden berdasarkan diabetes mellitus yaitu responden yang menderita Diabetes Mellitus adalah sebanyak $20(18,5 \%)$ responden dan yang tidak menderita diabetes mellitus sebanyak $88(81,5 \%)$ responden.

Tabel 9. Distribusi Responden Berdasarkan Diabetes Mellitus di Puskesmas Kota Tahun 2020

\begin{tabular}{ccc}
\hline Kadar Gula Darah & $\mathbf{N}$ & $\mathbf{\%}$ \\
\hline Diabetes mellitus & 20 & 18.5 \\
Tidak diabetes mellitus & 88 & 81.5 \\
\hline Total & $\mathbf{1 0 8}$ & $\mathbf{1 0 0 . 0}$ \\
\hline
\end{tabular}

Sumber data primer, 2020

\section{j. Distibusi responden berdasarkan Asm}

Pada Tabel 10 menunjukan bahwa distribusi responden berdasarkan asma dengan penderita sebanyak 3 (2,8\%) responden dan dan yang tidak menderita sebanyak 105 (97,2\%) responden.

Tabel 10. Distribusi Responden Berdasarkan Asma di Puskesmas Kota Tahun 2020

\begin{tabular}{lccc}
\hline & Asma & $\mathbf{N}$ & $\mathbf{\%}$ \\
\hline Asma & & 3 & 2.8 \\
Tidak asma & & 105 & 97.2 \\
\hline & Total & $\mathbf{1 0 8}$ & $\mathbf{1 0 0 . 0}$ \\
\hline
\end{tabular}

Sumber data primer, 2020

\section{k. Distribusi responden berdasarka Pneumonia}

Pada Tabel 11 menunjukan bahwa distribusi responden berdasarkan asma yaitu yang menderita Asma sebanyak 3 (2,8\%) responden dan yang tidak menderita Asma sebanyak 105 $(97,2 \%)$ responden.

Tabel 11. Distribusi Responden Berdasarkan Pneumonia di Puskesmas Kota Tahun 2020

\begin{tabular}{cccc}
\multicolumn{1}{c}{ Pneumonia } & $\mathbf{N}$ & $\mathbf{\%}$ \\
\cline { 1 - 1 } $\begin{array}{c}\text { Pneumonia } \\
\text { Tidak pneumonia }\end{array}$ & 3 & & 2.8 \\
\hline Total & 105 & & 97.2 \\
\hline
\end{tabular}

Sumber data primer, 2020

\subsection{Analisis Bivariat}

a. Distribusi responden berdasarkan hipertensi dengan kejadian covid-19

Pada tabel 12 menunjukan bahwa dari 108 responden terdapat penderita hipertensi dengan kategori parah dan tidak parah masing-masing sebanyak 10 responden $(9,3 \%)$, sedangkan responden yang tidak menderita hipertensi dengan kategori parah sebanyak 15 responden $(13,9 \%)$ dan dengan kategori tidak parah sebanyak 73 responden $(67,6 \%)$. 
Berdasarkan hasil uji statistik diperoleh nilai $p=0,002<0,5$ sehingga hopotesis Ho ditolak yang berarti hipertensi merupakan faktor komorbid terhadap kejadian covid-19 di Puskesmas Kota Tahun 2020

Tabel 12. Analisis Hubungan Faktor Komorbid Hipertensi Dengan Kejadian Covid-19 Di Puskesmas Kota Tahun 2020

\begin{tabular}{|c|c|c|c|c|c|c|c|}
\hline \multirow{3}{*}{ Hypertensi } & \multicolumn{4}{|c|}{ Covid-19 } & \multirow{2}{*}{\multicolumn{2}{|c|}{ Total }} & \multirow{3}{*}{ P-Value } \\
\hline & \multicolumn{2}{|c|}{ Parah } & \multicolumn{2}{|c|}{ Tidak parah } & & & \\
\hline & $\mathrm{N}$ & $\%$ & $\mathrm{~N}$ & $\%$ & $\mathrm{~N}$ & $\%$ & \\
\hline $\mathrm{Ya}$ & 10 & 9,3 & 10 & 9,3 & 20 & 18,5 & 0,002 \\
\hline Tidak & 15 & 13,9 & 73 & 67,6 & 88 & 81,5 & \\
\hline Jumlah & 25 & 23.1 & 83 & 76,9 & 108 & 100,0 & \\
\hline
\end{tabular}

\section{b. Distribusi responden berdasarkan diabetes mellitus dengan kejadian covid-19}

Pada tabel 13 menunjukan bahwa dari 108 responden terdapat penderita Diabetes mellitus dengan kategori parah sebanyak 11 responden (10,2\%), dan tidak parah sebanyak 9 responden $(8,3 \%)$, sedangkan responden yang tidak menderita Diabetes mellitus dengan kategori parah sebanyak 14 responden $(13,0 \%)$ dan dengan kategori tidak parah sebanyak 74 responden $(68,5 \%)$.

Tabel 13. Analisis Hubungan Faktor Komorbid Diabetes Mellitus Dengan Kejadian Covid-19 Di Puskesmas Kota Tahun 2020

\begin{tabular}{|c|c|c|c|c|c|c|c|}
\hline \multirow{3}{*}{$\begin{array}{l}\text { Diabetes } \\
\text { mellitus }\end{array}$} & \multicolumn{4}{|c|}{ Covid-19 } & \multirow{2}{*}{\multicolumn{2}{|c|}{ Total }} & \multirow[b]{2}{*}{ P-Value } \\
\hline & \multicolumn{2}{|c|}{ Parah } & \multicolumn{2}{|c|}{ Tidak parah } & & & \\
\hline & $\mathrm{N}$ & $\%$ & $\mathrm{~N}$ & $\%$ & $\mathrm{~N}$ & $\%$ & \multirow{4}{*}{0,000} \\
\hline $\mathrm{Ya}$ & 11 & 10,2 & 9 & 8,3 & 20 & 18,5 & \\
\hline Tidak & 14 & 13,0 & 74 & 68,5 & 88 & 81,5 & \\
\hline Jumlah & 25 & 23.1 & 83 & 76,9 & 108 & 100,0 & \\
\hline
\end{tabular}

Sumber data primer, 2020

Berdasarkan hasil uji statistik diperoleh nilai $p=0,000<0,5$ sehingga hopotesis Ho ditolak yang berarti diabetes mellitus merupakan faktor komorbid terhadap kejadian covid-19 di Puskesmas Kota Tahun 2020.

\section{c. Distibusi responden berdasarkan asma dengan kejadian covid-19}

Pada tabel 14 menunjukan bahwa dari 108 responden terdapat penderita Asma dengan kategori parah sebanyak 3 responden $(2,8 \%)$ dan tidak parah 0 responden, sedangkan responden yang tidak menderita Asma dengan kategori parah sebanyak 22 responden $(20,4 \%)$ dan dengan kategori tidak parah sebanyak 83 responden $(76,9 \%)$.

Tabel 14. Analisis Hubungan Faktor Komorbid Asma Dengan Kejadian Covid-19 Di Puskesmas Kota Tahun 2020

\begin{tabular}{|c|c|c|c|c|c|c|c|}
\hline \multirow{3}{*}{ Asma } & \multicolumn{4}{|c|}{ Covid-19 } & \multirow{2}{*}{\multicolumn{2}{|c|}{ Total }} & \multirow[t]{3}{*}{ P-Value } \\
\hline & \multicolumn{2}{|c|}{ Parah } & \multicolumn{2}{|c|}{ Tidak parah } & & & \\
\hline & $\mathrm{N}$ & $\%$ & $\mathrm{~N}$ & $\%$ & $\mathrm{~N}$ & $\%$ & \\
\hline $\mathrm{Ya}$ & 3 & 2,8 & 0 & 0 & 3 & 2,8 & 0,001 \\
\hline Tidak & 22 & 20,4 & 83 & 76,9 & 105 & 92,2 & \\
\hline Jumlah & 25 & 23.1 & 83 & 76,9 & 108 & 100,0 & \\
\hline
\end{tabular}

Sumber data primer, 2020

Berdasarkan hasil uji statistik diperoleh nilai $p=0,001<0,5$ sehingga hopotesis Ho ditolak yang berarti asma merupakan faktor komorbid kejadian covid-19 di Puskesmas Kota Tahun 2020.

\section{d. Distribusi responden berdasarkan pneumonia dengan kejadian covid-19}

Pada tabel 15 menunjukan bahwa dari 108 responden terdapat penderita Pneumonia dengan kategori parah sebanyak 1 responden $(0,9 \%)$ dan tidak parah 2 responden $(1,9 \%)$, sedangkan 
responden yang tidak menderita Pneumonia dengan kategori parah sebanyak 24 responden $(22,2 \%)$ dan dengan kategori tidak parah sebanyak 81 responden $(75,0 \%)$.

Tabel 15. Analisis Hubungan Faktor Komorbid Pneumonia Dengan Kejadian Covid-19 Di Puskesmas Kota Tahun 2020

\begin{tabular}{|c|c|c|c|c|c|c|c|}
\hline \multirow[t]{3}{*}{ Pneumonia } & \multicolumn{4}{|c|}{ Covid-19 } & \multirow{2}{*}{\multicolumn{2}{|c|}{ Total }} & \multirow[t]{2}{*}{ P-Value } \\
\hline & \multicolumn{2}{|c|}{ Parah } & \multicolumn{2}{|c|}{ Tidak parah } & & & \\
\hline & $\mathrm{N}$ & $\%$ & $\mathrm{~N}$ & $\%$ & $\mathrm{~N}$ & $\%$ & \\
\hline Ya & 1 & 0,9 & 2 & 1,9 & 3 & 2,8 & 0,671 \\
\hline Tidak & 24 & 22,2 & 81 & 75,0 & 105 & 92,2 & \\
\hline Jumlah & 25 & 23.1 & 83 & 76,9 & 108 & 100,0 & \\
\hline
\end{tabular}

Berdasarkan hasil uji statistik diperoleh nilai $p=0,671>0,5$ sehingga hopotesis Ho diterima yang berarti pneumonia bukan merupakan faktor komorbid kejadian covid-19 di Puskesmas Kota Tahun 2020.

\subsection{Analisis Multivariat}

Tabel 16. Hasil Uji Regresi Logistik Faktor Risiko Penyakit Komorbid Terhadap Kejadian Covid-19 di Puskesmas Kota Tahun 2020

\begin{tabular}{crrrrrrr}
\hline \multicolumn{7}{c}{ Variables in the Equation } \\
\hline Variabel & \multicolumn{1}{c}{ B } & \multicolumn{1}{c}{ S.E. } & Wald & df & \multicolumn{1}{c}{ Sig. } & \multicolumn{1}{c}{ Exp(B) } \\
\hline HIPERTENSI & 1.150 & .642 & 3.211 & 1 & .073 & 3.159 \\
DM & 1.349 & .646 & 4.356 & 1 & .037 & 3.852 \\
ASMA & 22.828 & $2.251 \mathrm{E} 4$ & .000 & 1 & .999 & $8.201 \mathrm{E} 9$ \\
\hline Constant & -48.683 & $4.501 \mathrm{E} 4$ & .000 & 1 & .999 & .000 \\
\hline
\end{tabular}

a. Variable(s) entered on step 1: HIPERTENSI, DM, ASMA.

Berdasarkan Tabel 16 hasil uji regresi logistik menunjukkan bahwa Diabetes Mellitus yang menjadi faktor risiko penyakit komorbid terhadap kejadian covid-19 di puskesmas kota tahun 2020 . dengan nilai signifikansi 0.037 atau p-value $<0.05, \beta=3.385$ dengan demikian Diabetes Mellitus . merupakan factor komorbid yang paling berpengaruh terhadap kejadian Covid-19 di Puskesmas Kota Ternate Tahun 2020.

\section{PENUTUP}

Berdasarkan hasil penelitian tentang faktor risiko komorbid terhadap kejadian covid-19 di Puskesmas Kota Tahun 2020 disimpulkan bahwa hasil analisis bivariat menyatakan bahwa hypertensi, diabetes mellitus, dan asma memiliki hubungan yang signifikan dan Pneumonia tidak memiliki hubungan yang signifikan terhadap kejadian covid-19 di Puskesmas Kota Tahun 2020, sedangkan hasil analisis multivariat terdapat pengaruh antara diabetes mellitus terhadap covid-19 dengan nilai signifikan $p 0.037$ atau p-value $<0.05, \beta=3.385$ di Puskesmas Kota Tahun 2020, maka Ha di terima dan Ho ditolak yang artinya diabetes mellitus merupakan faktor komorbid yang sangat berpengaruh 3.385 kali lipat pada penderita Covid-19.

Berdasarkan hasil analisis, maka saran yang dapat disampaikan yaitu untuk Puskesmas setempat perlu meningkatkan promosickesehatan tentang faktor risiko komorbid dalam hal ini penyakit Hypertensi, Diabetes mellitus dan Asma terkait hubungannya dengan kejadian Covid-19. serta diharapkan penderita Covid-19 dapat meningkatkan kesadaran dan kewaspadaan terhadap kondisi kesehatannya dengan selalu menjaga sisitim imun tubuh dan melakukan protocol kesehatan dan keterbatasan sampel maka Kepada peneliti bisa melanjutkan penelitian dengan jumlah sampel yang lebih banyak, dan variabel yang berbeda, juga dengan analisis uji statitik yang berbeda, bisa juga penelitian dilanjutkan dengan melihat kasus dan kontrol ataupun desaign cohort 


\section{DAFTAR PUSTAKA}

Chang T, Wu J, Chang L. Since January 2020 Elsevier has created a COVID-19 resource centre with free information in English and Mandarin on the novel coronavirus COVID- research that is available on the COVID-19 resource centre - including this ScienceDirect Clinical characteris. J Formos Med Assoc. 2020;(January).

Gunawan, A Kartika P, Muhamad RU, Muhammad P A. 2020. Pengaruh Komorbid Hipertensi Terhadap Severitas Pasien Coronavirus Disease 2019. Jurnal Implementa Husada. Vol 1 No 2 Agustus 2020 hlm 136-151 Jurnal.umsu.ac.id/index.php/JIH

Huang C, Wang Y, Li X, Ren L, Zhao J, Hu Y, et al. Clinical feature of patients infected with 2019 novel coronavirus in Wuhan, China. Lancet.2020;395(10223):497-506

Profi Puskesma Kota Tahun 2020

Comorbidity Seacrh online Etomologi Dictionary. www.etymonline. Diakses pada tanggl Agustus 2020

Hasibuan,L. 2020 Hipertensi \& Diabetes, 2 Penyakit Picu Kematian Pasien Corona. https://www.cnbcindonesia.com/lifestyle/20200415120218-33-152068/hipertensidiabetes-2-penyakit-picu-kematian-pasien-corona.

AHA (american Heart Association). (2017). Hypertension : The Silent Killer : Updated JNC-8 Guideline Recommendations. Alabama Pharmacy Association. https://doi.org/0178-0000-15-104H01-P

Riset Kesehatan Dasar,2018

Damayanti,S, 2015. Buku ajar ilmu edokrin, diabetes mellitus, dan penatalaksanaan keperawatan, Nuhamediaka, Yogyakarta

Dewi,R.K,2015. Diabetes bukan untuk ditakuti. Jakarta :Fmedia

Irmalita, 2015. Pedoman tatalaksana sindrom koroner akut. Perhimpunan dokter spesialis kardiovaskuler Indonesia. Kedisi kelima

Smelrzer, Susan ,C, 2014. Keperawat Degeneratif an medical - bedah. Jakarta;EGC.

Ip Suiraoka. 2012. Penyakit. Yogyakarta: Nuha Medika.

Irwan. (2016). Epidemiologi Penyakit Tidak Menular. Yogyakarta : Deepublish.

Werdhani, R.A. 2011. Pedoman nasional penanggulangan tubelkolosis. Jakarta:EGC

Kowalak. 2011. Buku Ajar Patofisiologi. Jakarta: EGC

Dahlan Z. Pneumonia. In Setiati S, Alwi I, Sudoyo AW, Simadibrata M, Setyohadi B, Syam AF (Eds). Buku Ajar Ilmu Penyakit Dalam. 6th ed. Jakarta: Pusat Penerbitan Ilmu Penyakit Dalam FKUI; 2014. p1608-19.

Callistania, C., \& Indrawati, W. (2014). Pneumonia. Dalam: Tanto, C.,Liwang, F.,Hanifati, S., \& Pradipta, E.A. (Eds.), Kapita Selekta Kedokteran. Jakarta:Media Aesculapius

Said M, 2015, Buku Ajar Respirologi Anak, 1th Ed, Ikatan Dokter Anak Indonesia, Jakarta.

Fauzi, Isma. 2014. Buku Pintar Deteksi Dini Gejala, \& Pengobatan Asam Urat, Diabetes \& Hipertensi. Yogyakarta: Araska. 
Muttaqin, Arif \& Sari, Kurmala. 2011. Gangguan Gastrointestinal : Aplikasi Asuhan Keperawatan Medikal bedah. Jakarta : Salemba medika.

Soeharto. 2015. Serangan Jantung dan Stroke Hubungannya dengan Lemak dan Kolesterol, Edisi Keenam, Gramedia Pustaka Utama, Jakarta.

Nursalam. Batticaca, B. Fransisca. 2011. Asuhan Keperawatan pada Pasien dengan Gangguan Sistem Perkemihan. Jakarta : Salemba Medika.

Kemenkes. (2014). strategi nasional pengendalian TB di Indonesia tahun 2013 - 2017. Jakarta : Direktorat Jenderal Pencegahan dan Pengendalian Penyakit Menular Kemenkes RI, 2014.

Kementerian kesehatan RI, 2020. Direktorat pencegahan dan pengendalian penyakit tidak menular Direktorat jenderal pencegahan dan pengendalian penyakit. http://www.p2ptm.kemkes.go.id/

Notoatmodjo, S. 2010. Metodologi Penelitian Kesehatan. Jakarta : Rineka Cipta.

Notoatmodjo, S. 2010. Metodologi Penelitian Kesehatan. Jakarta : Rineka Cipta.Huang C, Wang Y, Li X, Ren L, Zhao J, Hu Y, et al. Clinical feature of patients infected with 2019 novel coronavirus in Wuhan, China. Lancet.2020;395(10223):497-506.. 